\title{
Seasonal Incidence and Population Dynamics of Major Insect Pest Species of Paddy Collected in Light Trap in Relation to Weather Parameters
}

\author{
S.K. Meena, A.K. Sharma and Rajesh Aarwe* \\ Department of Entomology, College of Agriculture, Jawaharlal Nehru Krishi Vishwa \\ Vidyalaya, Jabalpur-482004, Madhya Pradesh, India \\ *Corresponding author
}

\section{A B S T R A C T}

\begin{tabular}{|l|}
\hline K e y w o r d s \\
$\begin{array}{l}\text { Light trap, Rice, } \\
\text { Lepidoptera, Hemiptera, } \\
\text { Orthoptera, Species }\end{array}$ \\
\hline Article Info \\
\hline $\begin{array}{l}\text { Accepted: } \\
10 \text { July } 2018 \\
\text { Available Online: } \\
10 \text { August } 2018\end{array}$ \\
\hline
\end{tabular}

\section{Introduction}

Rice (Oryza sativa L.) is an important cereal crop in the world serving as staple diet for millions of peoples. Rice stand second in the world after wheat in area and production. Almost $90 \%$ of rice is grown and consumed in Asia (Anonymous, 2006).

At global level, rice is grown on an area of about 155.2 million ha with production and productivity of 461 million tonnes and 4.09 tonne $\mathrm{ha}^{-1}$ respectively. India ranks first in respect of area 43.95 million ha second in production 106.54 million tonne, only after China, but the productivity of rice is very low only 2.42 tonne $\mathrm{ha}^{-1}$. In Madhya Pradesh rice is cultivated in area of 1.93 million ha with production of 2.78 million tonne and productivity of 1.44 tonne ha ${ }^{-1}$ (Anonymous, 2014).

Worldwide food plants are damaged by more than 10,000 species of insects (Dhaliwal et al., 2007). In India, average losses of paddy production due to insect pests are $25-30 \%$ (Dhaliwal and Arora, 2010) and in Madhya Pradesh about 40-100 \% losses were observed (Dhamdhere, 1990).

Nocturnal insects are often attracted to light sources that emit large amount of UV radiation, and devices that exploit this behavior, such as light traps for forecasting pest outbreaks, and electric insect killers, have been developed (Shimoda and Honda, 2013). 
Garris and Snyder (2010) reported that phototactic behavior toward ultraviolet light varies among nocturnal flying insects.

Sinu et al., (2013) suggested that that light trap is an effective, bias-free monitoring tool of moth pests, it has often been used in the ecological studies of lepidopteron insect pests in agro-ecosystems. Sharma et al., (2004) suggested that light trap is an important tool for minimizing the insect pests damage without any toxic hazards.

Vaishampayan (2002) proposed a new concept of adult-oriented pest management strategy, which is based on the suppression of pest population through mass trapping and killing of adults using their behavioral responses (visual, olfactory, gustatory, sexual reproductive, biological, etc.) and describe the salient points of using light traps as a component of such strategy.

Now the use of light trap has become a common tool for various studies in entomological research.

Majority of these rice insect pests are phototactic in nature. Therefore light traps can be used as an effective IPM tool for monitoring and management of phototactic paddy pests. Sharma (2004) monitored the seasonal activity of 14 major and minor insect pest species of paddy through light trap at Jabalpur, similarly Sharma and Vaishampayan (2009) ${ }^{[20]}$ evaluated light trap as direct control tool against four major pest species of paddy in Jabalpur, M.P., with exception of army worm Mythimna separata (Walker) results have consistently proved the utility of light trap as direct control tool againest remaining three major species namely Sogatella furcifera (Horvath) Cnaphalocrocis medinalis (Guenee) and grass hopper (Complex). Effective coverage area was between 100-200 m distances from trap covering around 5 to 6 ha of crop area per trap. The present investigation is proposed to observe the "Seasonal Incidence and Population Dynamics of Major Insect Pest Species of Paddy Collected in Light Trap In Relation To Weather Parameters".

\section{Materials and Methods}

The present experiment entitled, "Seasonal incidence and population dynamics of major insect pest species of paddy collected in light trap in relation to weather parameters" was carried out at the Krishi Nagar experimental farm, Adhartal, JNKVV, Jabalpur, Madhya Pradesh during the period between last week of June to last week of December, 2014.

\section{Details of light trap unit}

New Jawahar light trap model developed at JNKVV, Jabalpur with mercury vapor lamp $(80 \mathrm{~W})$ as light source was used for the present study. The light trap units comprised of two components are as follows:-

\section{Trapping device}

It is made up of 24 gauge GI sheet consisting of a funnel (40 cm top diameter), baffle plates each $30 \times 12 \mathrm{~cm}$ in size. In this design long funnel stem (pipe) is provided in place of collection chamber which is directly attached to collection trey.

\section{Insect collection device}

It is made up of 24 gauge GI sheet $40 \mathrm{~cm} \mathrm{x} 40$ $\mathrm{cm} \times 15 \mathrm{~cm}$ in size with cupboard and built-in locking system. The insects collected in the chamber of light trap were killed by the exposure of Dichlorvos 76 EC vapours (as fumigating agent) which is directly placed in collection tray for instant killing of trapped insects. 


\section{Observation procedure}

Seasonal activity study of major insect pest species of paddy was recorded by operating the light trap in Kharif season of 2014. Major and minor pests of paddy were observed on daily basis. In order to study the seasonal activity, daily trap catch was converted into weekly total and mean per day per week (weekly mean/day).

Weekly divisions are based on standard meteorological week. Observations of weather data (Maximum temperature, Minimum temperature, relative humidity morning \& evening, rainfall, number of rainy days, sunshine hours, wind velocity, morning \& evening vapour pressure and evaporation etc.) were recorded on daily basis from JNKVV meteorological observatory.

The correlation coefficient between major insect pests of paddy and various weather parameters was calculated by using the correlation regression analysis.

\section{Statistical method}

Correlation and regression of the abiotic factors on major insects were worked out by using the formula as suggested by Snedecor and Cochran (1967).

Correlation ' $\mathrm{r}^{\prime}=\frac{\sum x y-\frac{\sum x_{2} \sum y}{n}}{\sqrt{\left\{\sum_{x} 2-\frac{\left(\left(\sum x\right)^{2}\right)}{n}\right\}\left\{\sum \sum_{y} 2-\frac{\left(\left(\sum y\right)^{2}\right)}{\mathrm{N}}\right\}}}$

$\operatorname{Regression}^{\widehat{\mathrm{Y}}}=\mathrm{a}+\mathrm{bx}\left(\mathrm{R}^{2}\right)$

$\mathrm{a}=$ Intercept.

$\mathrm{b}=$ Regression coefficient

$\mathrm{R}^{2}=$ Coefficient of multiple determination.
Test of significance ' $r$ '

$t=\frac{r}{\sqrt{1-r^{2}}} \sqrt{n-2}$

\section{Results and Discussion}

Seasonal activity of major insect pest species of paddy collected in light trap were studied by operating, Jawahar light trap (with 80 Watt mercury vapour lamp) in paddy field at Krishi Nagar experimental farm, Adhartal during kharif 2014.

In all 8 species were identified as pests of paddy having regular occurrence in light trap catches (Table 1).

\section{Correlation studies}

The correlation coefficients among various insect population and weather parameters viz., maximum temperature, minimum temperature, sunshine, wind velocity, morning relative humidity, evening relative humidity, rainfall, morning vapor pressure, evening vapor pressure, evaporation and number of rainy days have been computed.

\section{Army worm, Mythimna separata (Walker)}

Army worm was first recorded during $34^{\text {rth }}$ SW (standard week) in light trap. The activity period of Mythimna separata (Walker) was observed from mid of August to December with two distinct peaks during $40^{\text {th }}$ and $44^{\text {rth }}$ SW. The highest peak was observed in $44^{\text {rth }}$ SW (Table 1).

In accordance with the present findings Muchhala (2014) also reported two distinct peaks of $M$. separata during $39^{\text {th }}$ and $44^{\text {rth }} \mathrm{SW}$, while Sharma et al., (2013) reported that highest peaks of $M$. separata were observed during third week of September and November. Sharma et al., (2002) also reported 
that Mythimna separata (Walker) was observed highest in trap catches during September.

Correlation between various weather parameters and adults of army worm moth catches were found non-significant (Table 2).

On contrast to the present findings, Muchhala (2014) reported that maximum temperature and evaporation exhibited a significant positive effect on moths catches, while Sharma et al., (2013) found that higher rainfall, lower mean maximum temperature and higher relative humidity were favourable for M. separata. Sharma et al., (2002) reported that rainfall, morning and evening relative humidity were positively associated with trap catches, while maximum temperature, evaporation, sunshine and wind velocity showed a negative correlation with trap catches of $M$. separata.

\section{Rice leaf folder, Cnaphalocrocis medinalis (Guenee)}

Rice leaf folder was first recorded during $38^{\text {rth }}$ $\mathrm{SW}$ in light trap. The activity period of $C$. medinalis was observed from September to December. Two distinct peaks were recorded in $40^{\text {th }} \mathrm{SW}$ and $44^{\text {rth }} \mathrm{SW}$. The highest peak was observed in $44^{\text {rth }} \mathrm{SW}$ (Table 1). In accordance with the present findings, Patel et $a l$., (2011) reported that rice leaf folder, $C$. medinalis reached its peak level during $43^{\text {rd }}$ SW, Khan and Ramamurthy (2004) revealed that the moth numbers were higher in the month of October, followed by September.

In contrary of present findings, Hafeez et al., (2010) reported that adults of leaf folder start in light trap catches during $26^{\text {th }} \mathrm{SW}$ and reached its highest peak in $33^{\text {rd }} \mathrm{SW}$, while Sharma et al., (2013) from Jabalpur recorded three to four peaks of rice leaf folder during the main cropping season (kharif) of paddy. Harinkhere et al., (1998) reported that first appearance of $C$. medinalis in trap catches started from first week of August and major peaks were observed during September and October at Balaghat (M.P.). However Manisegaran and Letchoumanane (2001) reported that weekly catches of rice leaf folder was highest during August and September in Tamil Nadu.

Correlation between rice leaf folder catch and maximum temperature minimum temperature, morning vapor pressure and evaporation found significant positive, while rest of weather parameters found non-significant (Table 2).

In accordance with present findings, Patel et al., (2011) reported that Maximum temperature $(\mathrm{r}=0.726)$ had significant positive correlation with trap catches. Hafeez et al., (2010) reported that minimum temperature $(\mathrm{r}=0.513)$ had a significant positive effect on trap catches. In contrary to current findings, Muchhala (2014) observed that all the weather parameters did not show any significant effect on moth catches, while Patel et al., $(2011)^{[15]}$ reported that wind velocity $(\mathrm{r}=-0.539)$ and rainy days $(\mathrm{r}=-0.518)$ had significant negative correlation. Sabir et al., (2006) ${ }^{[18]}$ observed that the maximum and minimum temperature have negative effect, while rainfall having positive effect on trap catches of $C$. medinalis. Kathirvelu and Manickavasgam (2007) also reported that leaf folder had significant negative correlation with maximum temperature and significant positive correlation with sunshine.

\section{Rice butterfly, Melanitis leda ismene Cramer}

Rice butterfly was first recorded during $33^{\text {rd }}$ SW in light trap. The activity period of $M$. leda ismene was observed from mid of August to November with three distinct peaks during $39^{\text {th }}, 42^{\text {nd }}$ and $45^{\text {th }} \mathrm{SW}$, respectively. 
Table.1 Seasonal activity of insect pest species of paddy during kharif 2014 (June to December) (Weekly average)

\begin{tabular}{|c|c|c|c|c|c|c|c|c|}
\hline SW & $\begin{array}{l}\text { Mythimna } \\
\text { separata } \\
\text { (Walker) }\end{array}$ & $\begin{array}{l}\text { Cnaphalocrosis } \\
\text { medinalis (Guenee) }\end{array}$ & $\begin{array}{l}\text { Melanitis leda } \\
\text { ismene Cramer }\end{array}$ & $\begin{array}{l}\text { Leptocorisa } \\
\text { acuta } \\
\text { (Thunberg) }\end{array}$ & $\begin{array}{l}\text { Nephotettix } \\
\text { virescens } \\
\text { (Distant) }\end{array}$ & $\begin{array}{l}\text { Tetrix } \\
\text { subulata } \\
\text { Linnaeus }\end{array}$ & $\begin{array}{l}\text { Euscyrtus } \\
\text { concinnus } \\
\text { (de Haan) }\end{array}$ & $\begin{array}{l}\text { Gryllotalpa } \\
\text { orientalis } \\
\text { Burmeister }\end{array}$ \\
\hline 26 & 0 & 0 & 0 & 0 & 0 & 0.57 & 39.85 & 0.71 \\
\hline 27 & 0 & 0 & 0 & 0 & 3.42 & 0.57 & 102.42 & 2.85 \\
\hline 28 & 0 & 0 & 0 & 0 & 11.14 & 0.71 & 147.42 & 3.14 \\
\hline 29 & 0 & 0 & 0 & 0 & 13 & 1 & 218.14 & 4 \\
\hline 30 & 0 & 0 & 0 & 0 & 7.28 & 1.14 & 300.42 & 4.85 \\
\hline 31 & 0 & 0 & 0 & 1.71 & 11.71 & 1.14 & 304.85 & 6.57 \\
\hline 32 & 0 & 0 & 0 & 1.85 & 4 & 5.71 & 321.42 & 15 \\
\hline 33 & 0 & 0 & 0.42 & 1.71 & 6.71 & 3.42 & 343.85 & 13 \\
\hline 34 & 0.28 & 0 & 0.42 & 2.14 & 21.42 & 1.85 & 340.71 & 14.28 \\
\hline 35 & 1.14 & 0 & 0.57 & 2.71 & 10 & 0.85 & 298.57 & 12 \\
\hline 36 & 0.42 & 0 & 0.71 & 3.57 & 11.14 & 0.71 & 263 & 15.42 \\
\hline 37 & 1.14 & 0 & 0.85 & 0.42 & 4.28 & 0.14 & 228 & 11 \\
\hline 38 & 3.14 & 0.71 & 0.85 & 0 & 11.57 & 2.28 & 220 & 5.85 \\
\hline 39 & 2.57 & 3.14 & 1 & 0.28 & 9.57 & 1.85 & 152.85 & 17.71 \\
\hline 40 & 7.71 & 3.42 & 0.57 & 3.14 & 48 & 1.57 & 119.28 & 17.57 \\
\hline 41 & 2.57 & 1.57 & 1.14 & 3.42 & 84.42 & 1.14 & 28.28 & 17.42 \\
\hline 42 & 5.14 & 2.42 & 2.14 & 15.85 & 159.14 & 1 & 166 & 8.28 \\
\hline 43 & 3.85 & 2 & 0.42 & 11.57 & 143.42 & 0.14 & 156.71 & 4.85 \\
\hline 44 & 36.71 & 3.71 & 0.42 & 8.14 & 34.85 & 0.71 & 25.71 & 0.85 \\
\hline 45 & 22.85 & 2.28 & 2.28 & 0.85 & 13.57 & 0.42 & 19 & 1.42 \\
\hline 46 & 17.71 & 1.85 & 0.57 & 0 & 0 & 0.28 & 15.71 & 2.71 \\
\hline 47 & 2.57 & 0.42 & 0 & 0 & 0 & 0.14 & 7.71 & 0.71 \\
\hline 48 & 3 & 1.14 & 0 & 0 & 0 & 0 & 6.14 & 0.57 \\
\hline 49 & 2.57 & 0.14 & 0 & 0 & 0 & 0 & 4.71 & 0.71 \\
\hline 50 & 0.85 & 0.57 & 0 & 0 & 0 & 0 & 2.57 & 0.57 \\
\hline 51 & 2.14 & 0.71 & 0 & 0 & 0 & 0 & 1.85 & 0.42 \\
\hline 52 & 0.71 & 0 & 0 & 0 & 0 & 0 & 0.28 & 0 \\
\hline
\end{tabular}


Table.2 Correlation coefficient of weather factors on light trap catches of Mythimna separata (Walker), Cnaphalocrocis medinalis (Guenee) and Melanitis leda ismene Cramer

\begin{tabular}{|c|c|c|c|c|c|c|}
\hline \multirow[t]{2}{*}{ Weather Parameter } & \multicolumn{2}{|c|}{ Mythimna separata (Walker) } & \multicolumn{2}{|c|}{ Cnaphalocrocis medinalis (Guenee) } & \multicolumn{2}{|c|}{ Melanitis leda ismene Cramer } \\
\hline & $\mathbf{R}$ & Вyx & $\mathbf{R}$ & Вyx & $\mathbf{R}$ & Byx \\
\hline Maximum temperature $\left({ }^{\circ} \mathrm{C}\right)$ & $-0.170 \mathrm{NS}$ & - & 0.549* & 0.222 & $0.207 \mathrm{NS}$ & - \\
\hline Minimum temperature $\left({ }^{\circ} \mathrm{C}\right)$ & $-0.119 \mathrm{NS}$ & - & $0.617 *$ & 0.113 & $0.075 \mathrm{NS}$ & - \\
\hline Sunshine (hrs) & $0.163 \mathrm{NS}$ & - & $0.322 \mathrm{NS}$ & - & $0.278 \mathrm{NS}$ & - \\
\hline Rainfall (mm) & $0.268 \mathrm{NS}$ & - & $-0.183 \mathrm{NS}$ & - & $-0.299 \mathrm{NS}$ & - \\
\hline Morning relative humidity (\%) & $-0.151 \mathrm{NS}$ & - & $0.013 \mathrm{NS}$ & - & $0.284 \mathrm{NS}$ & - \\
\hline Evening relative humidity $(\%)$ & $-0.404 \mathrm{NS}$ & - & $0.205 \mathrm{NS}$ & - & $-0.085 \mathrm{NS}$ & - \\
\hline Morning vapor pressure (mm) & $-0.179 \mathrm{NS}$ & - & $0.584 *$ & 0.126 & $0.095 \mathrm{NS}$ & - \\
\hline Evening vapor pressure (mm) & $-0.27 \mathrm{NS}$ & - & $0.493 \mathrm{NS}$ & - & $0.037 \mathrm{NS}$ & - \\
\hline Evaporation (mm) & $0.78 \mathrm{NS}$ & - & $0.561 *$ & 0.81 & $-0.085 \mathrm{NS}$ & - \\
\hline Number of rainy days & $-0.271 \mathrm{NS}$ & - & $-0.018 \mathrm{NS}$ & - & $-0.184 N S$ & - \\
\hline \multicolumn{2}{|c|}{ NS $=$ Non-Significant } & \multicolumn{3}{|c|}{$* .=$ Significant at 0.05 level } & \multicolumn{2}{|c|}{$* *=$ Significant at 0.01 level } \\
\hline
\end{tabular}

Table.4 Correlation coefficient of weather factors on light trap catches of Tetrix subulata Linnaeus Euscyrtus concinnus (de Haan) and Gryllotalpa orientalis Burmeister

\begin{tabular}{|c|c|c|c|c|c|c|}
\hline \multirow[t]{2}{*}{ Weather Parameter } & \multicolumn{2}{|c|}{ Tetrix subulata Linnaeus } & \multicolumn{2}{|c|}{ Euscyrtus concinnus (de Haan) } & \multicolumn{2}{|c|}{ Gryllotalpa orientalis Burmeister } \\
\hline & $\mathbf{R}$ & Byx & $\mathbf{R}$ & byx & $\mathbf{R}$ & Byx \\
\hline Maximum temperature $\left({ }^{\circ} \mathrm{C}\right)$ & $0.009 \mathrm{NS}$ & & 0.106 & - & $0.315 \mathrm{NS}$ & - \\
\hline Minimum temperature $\left({ }^{\circ} \mathrm{C}\right)$ & $0.492 * *$ & 0.089 & $0.747 * *$ & 13.64 & $0.559 * *$ & 0.513 \\
\hline Sunshine (hrs) & $-0.169 \mathrm{NS}$ & - & $-0.537 * *$ & -29.61 & $-0.060 \mathrm{NS}$ & - \\
\hline Rainfall (mm) & $0.338 \mathrm{NS}$ & - & $0.434 *$ & 0.773 & $0.96 \mathrm{NS}$ & - \\
\hline Morning relative humidity (\%) & $0.056 \mathrm{NS}$ & - & $0.289 \mathrm{NS}$ & - & $0.248 \mathrm{NS}$ & - \\
\hline Evening relative humidity (\%) & $0.473 *$ & 0.031 & $0.836 * *$ & 5.522 & $0.536 * *$ & 0.178 \\
\hline Morning vapor pressure (mm) & $0.526 * *$ & 0.117 & $0.831 * *$ & 18.33 & $0.632 * *$ & 0.701 \\
\hline Evening vapor pressure (mm) & $0.513 * *$ & 0.100 & $0.861 * *$ & 17.08 & $0.618 * *$ & 0.616 \\
\hline Evaporation (mm) & $0.199 \mathrm{NS}$ & - & $0.177 \mathrm{NS}$ & - & $0.095 \mathrm{NS}$ & - \\
\hline Number of rainy days & $0.270 \mathrm{NS}$ & - & $0.574 * *$ & 31.87 & $0.325 \mathrm{NS}$ & - \\
\hline \multicolumn{2}{|l|}{ NS = Non-Significant } & \multicolumn{3}{|c|}{$* .=$ Significant at 0.05 level } & \multicolumn{2}{|c|}{$* *=$ Significant at 0.01 level } \\
\hline
\end{tabular}


Table.3 Correlation coefficient of weather factors on light trap catches of Leptocorisa acuta (Thunberg) and Nephotettix virescens (Distant)

\begin{tabular}{|c|c|c|c|c|}
\hline \multirow[t]{2}{*}{ Weather Parameter } & \multicolumn{2}{|c|}{$\begin{array}{l}\text { Leptocorisa acuta } \\
\text { (Thunberg) }\end{array}$} & \multicolumn{2}{|c|}{$\begin{array}{l}\text { Nephotettix virescens } \\
\text { (Distant) }\end{array}$} \\
\hline & $\mathbf{R}$ & byx & $\mathbf{R}$ & Byx \\
\hline Maximum temperature $\left({ }^{\circ} \mathrm{C}\right)$ & $0.197 \mathrm{NS}$ & - & $0.320 \mathrm{NS}$ & - \\
\hline Minimum temperature $\left({ }^{\circ} \mathrm{C}\right)$ & $0.031 \mathrm{NS}$ & - & $-0.519 *$ & -6.603 \\
\hline Sunshine (hrs) & $0.215 \mathrm{NS}$ & - & $0.425 \mathrm{NS}$ & - \\
\hline Rainfall (mm) & $-0.227 \mathrm{NS}$ & - & $-0.435 \mathrm{NS}$ & - \\
\hline $\begin{array}{l}\text { Morning relative humidity } \\
(\%)\end{array}$ & $0.288 \mathrm{NS}$ & - & $0.244 \mathrm{NS}$ & - \\
\hline Evening relative humidity (\%) & $-0.039 \mathrm{NS}$ & - & $-0.387 N S$ & - \\
\hline Wind Velocity (km/hrs) & $-0.307 \mathrm{NS}$ & - & $-0.525 *$ & -12.47 \\
\hline Morning vapor pressure (mm) & $0.049 \mathrm{NS}$ & - & $-0.491 *$ & -6.933 \\
\hline Evening vapor pressure (mm) & $0.008 \mathrm{NS}$ & - & $-0.483 *$ & -5.161 \\
\hline Evaporation (mm) & $-0.163 N S$ & - & $-0.295 \mathrm{NS}$ & - \\
\hline Number of rainy days & $-0.177 \mathrm{NS}$ & - & $-0.455 \mathrm{NS}$ & - \\
\hline
\end{tabular}

The highest weekly peak was observed in $45^{\text {th }}$ SW (Table 1).

Similar to the present findings, Muchhala (2014) reported three distinct peaks during $38^{\text {rth }}, 42^{\text {nd }}$ and $44^{\text {rth }} \mathrm{SW}$, respectively. Major activity period was observed from August to December at Jabalpur.

In contrary to present findings, Sharma et al., (2004) from Jabalpur reported that major activity period of Melanitis leda ismene Cramer was observed in light trap from July to August and peak period was observed during September.

Correlation between various weather parameters and rice butterfly catches were found non-significant (Table 2).

In contrast to the present findings, Muchhala (2014) observed that maximum temperature exhibited a significant positive effect on butterfly catches.
Rice Gundhi bug, Leptocorisa acuta (Thunberg)

Rice gundhi bug was first recorded during $31^{\text {st }}$ SW in light trap. The activity period of Leptocorisa acuta (Thunberg) was observed from August to mid of November with two distinct peaks during $36^{\text {th }}$ and $42^{\text {nd }} \mathrm{SW}$. The highest peak was observed in $42^{\text {nd }} \mathrm{SW}$ (Table 1).

In accordance with the present findings, Sharma et al., (2011) also reported through light trap collection over 15 years that maximum population of $L$. acuta was observed during third week of October, while Venkatesh et al., (2009) reported that higher activity of ear head bug, Leptocorisa sp. was observed during September to October in kharif of 2006, which is in contrast to present findings. Correlation between various weather parameters and rice gundhi bug catches were found non-significant (Table 3). 
In contrast with the present findings, Sharma et al., (2004) found that rainfall had positive correlation of order 0.857 with population buildup of $L$. acuta whereas Bhatnagar and Saxena (1999) found a positive correlation between maximum temperature \& sunshine and trap catches of L. acuta, they also found significant negative correlation of minimum temperature, evening relative humidity and rainfall with light tap catches of $L$. acuta at Jagdalpur, India.

\section{Green leaf hopper, Nephotettix virescens (Distant)}

Green leaf hopper was first recorded during $27^{\text {th }} \mathrm{SW}$ in light trap. The activity period of $N$. virescens was observed from July to mid of November with two distinct peaks during $34^{\text {rth }}$ and $42^{\text {nd }} \mathrm{SW}$ respectively.

The highest weekly peak was observed in $42^{\text {nd }}$ SW (Table 1). The present finding confirms the finding of Sharma et al., (2004) ${ }^{[23]}$ who also reported that maximum population of $N$. virescens was recorded during the third week of October.

On the contrary of present findings, Sabale et al., (2010) also reported that first peak of green leaf hopper, $N$. virescens was observed during $38^{\text {rth }}$ to $41^{\text {st }} \mathrm{SW}$, the second peak was observed during $45^{\text {th }} \mathrm{SW}$ and the third peak was observed during $52^{\text {nd }}$ to $2^{\text {nd }} \mathrm{SW}$, respectively at Kelara. Srinavasa et al., (1991) recorded that $N$. virescens (Distant) was present throughout this period but showed peaks of abundance in November and May.

Correlation between minimum temperature, wind velocity, morning and evening vapor pressure showed significant negative effect on green leaf hopper catches, while rest of weather parameters were found nonsignificant (Table 3).
In contrast with the present findings, Kathirvelu and Manickavasgam (2007) observed that green leaf hopper were positively correlated with maximum \& minimum temperature, sunshine and rainy days, similarly Samim et al., (2009) revealed that the bright sunshine hours had a significant positive correlation $(r=0.166)$ with green leaf hopper.

\section{Short horn grass hopper, Tetrix subulata Linnaeus}

Short horn grass hopper was first recorded during $26^{\text {th }} \mathrm{SW}$ in light trap. The activity period was observed from June to mid of November with two distinct peaks during $32^{\text {nd }}$ SW and $38^{\text {rth }}$ SW. The highest peak was observed in $32^{\text {nd }} \mathrm{SW}$ (Table 1).

In contrast to the present findings, Sharma et al., $(2006)^{[22]}$ observed two species of grass hopper viz. Trilophidia cristella S. and Gastrimargus transversus T. in light trap catches in paddy field during 2002 (kharif season) at Jabalpur while Singh and Ramaneek (2007) reported that population fluctuations of twenty four species of orthopterans, were correlated with temperature and relative humidity,

In all six families viz. Gryllidae, Gryllotalpidae, Tettigoniidae (belonging to Suborder Ensifera) and Acrididae, Tridactylidae, and Tetrigidae (belonging to Suborder Caelifera) were collected. Gryllidae was found dominant followed by Tetrigidae as compared to other families.

Correlation between minimum temperature, evening relative humidity, wind velocity, morning vapor pressure and evening vapor pressure were showed significant positive correlation, while rest of weather parameters were found to non-significant with grass hopper catches (Table 4). 
Field cricket, Euscyrtus concinnus (de Haan)

Field cricket was first recorded during $26^{\text {th }}$ SW in light trap. The activity period of $E$. concinnus was observed from June to December with two distinct peaks during $33^{\text {rd }}$ and $42^{\text {nd }} \mathrm{SW}$. The highest peak was observed in $33^{\text {rd }} \mathrm{SW}$ (Table 1).

Similar to the present findings, Sharma et al., $(2004)^{[23]}$ also reported the major activity period of field cricket between July to October with maximum monthly catches during July, While Rathore (2001) reported that major activity period of field cricket was observed during September and October. Highest monthly catches were recorded during September (320 crickets) at Jabalpur.

Correlation between minimum temperature, rainfall, evening relative humidity, wind velocity, morning vapor pressure, evening vapor pressure and number of rainy days showed significant positive correlation and field cricket catches was found significantly positive, while sunshine exhibited a significant negative effect on crickets catches. Effect of maximum temperature, morning relative humidity and evaporation was found non-significant (Table 4).

\section{Mole cricket, Gryllotalpa orientalis Burmeister}

Mole cricket was first recorded during $26^{\text {th }}$ SW in light trap. The activity period of Gryllotalpa orientalis Burmeister was observed throughout the season (June to December) with three distinct peaks during $32^{\text {nd }}, 36^{\text {th }}$ and $39^{\text {th }} \mathrm{SW}$. The highest peak was observed in $39^{\text {th }} \mathrm{SW}$ (Table 1).

In contrast to the present findings, Wang et al., (2012) reported that the mole cricket
(Gryllotalpa sp.) had two damage peaks (late May to early July, early September to mid and late October) at Hangzhou (China), similarly Rathore (2001) also reported that major activity period of mole cricket was observed during September to October with highest monthly catches during September (285 crickets) at Jabalpur. Whereas Bhowmick (1985) reported that highest monthly catches of mole crickets were recorded during November (1395 adults) at Waraseoni, Balaghat, Madhya Pradesh.

Correlation between various weather parameters and mole cricket catches were found non-significant, except minimum temperature, evening relative humidity, morning vapor pressure and evening vapor pressure, which exhibited a significant positive effect on crickets catches (Table 4).

\section{References}

Anonymous, 2006. Rice in India hand book of statistics, Director of Rice Development, Government of India, Hyderabad (AP).

Anonymous, 2014. Agriculture Statistics at a glance, Department of Agriculture and co-operation, Ministry of Agriculture, Government of India, New Delhi.

Bhatnagar, A., and Saxena, RR. 1999. Environmental correlates of population build up of rice insect pests through light trap catches. Oryza 36(3): 241245.

Bhowmick, AK. 1985. Role of light trap in surveillance and management of insect pests of forest trees of major economic importance. Ph.D. Thesis, RDVV, Jabalpur.85p.

Dhaliwal, G.S., and Arora, R. 2010. Integrated Pest Management. Kalyani Publishers, New Delhi, India, 369 p.

Dhaliwal, G.S., Dhawan, A.K., and Singh, R. 2007. Biodiversity and Ecological 
Agriculture Issues and Prospectives. Indian Journal of Ecology 34(2): 100109.

Dhamdhere, SV. 1990. Phansalon Ke Pramukh Hanikark Keet. Haryana Sahitya Academy, Chandigarh. 374p.

Garris, H.W., and Snyder, JA. 2010. Sexspecific attraction of moth species to ultraviolet light traps. Southeastern Naturalist 9(3): 427-434.

Hafeez, A.K., Devinder Sharma, R.B., Jamwal, V.V.S., and Saurav, Gupta. 2010. Seasonal incidence, infestation and trap catches of Cnaphalocrocis mendinalis (Guenee) in rice. Annals of Plant Protection Sciences 18(2): 380383.

Harinkhere, J.P., Kandalkar, VS., and Bhowmick, AK. 1998. Seasonal abundance and association of light trap catches with field incidence of rice leaf folder (Cnaphalocrocis medinalis Guenee). Oryza 35(1): 91-92.

Kathirvelu, C., and Manickavasgam, S. 2007. Correlation of light trap catches of important parasitoids, predators and pest complex of rice with meteorological parameters. Hexapoda 14(1): 9-14.

Khan, Z.H., and Ramamurthy, VV. 2004. Influence of weather factors on the activity of rice leaf folder, Cnaphalocrocis medinalis (Guene). Annual of Plant Protection Sciences 12(2): 267-270.

Manisegaran, S., and Letchoumanane, S. 2001. Influence of weather factors on the population of rice leaf folder in the coastal region of Karaikal. Madras Agricultural Journal 88(7/9): 502-503.

Muchhala, Y. 2014. Study on insect pest fauna of paddy ecosystem collected in light trap in Jabalpur region. M.Sc Thesis, JNKVV, Jabalpur. 1-109p.

Patel, H.N., Kadu, RV., and Landge, SA. 2011. Study on seasonal incidence of rice leaf folders (Cnaphalocrocis medinalis Guen. and Pelopidas mathias $\mathrm{Fb}$.) of paddy and its correlation with weather parameters. International Journal of Plant Protection 4(1): 175180.

Rathore, MS. 2001. Studies on the major insect pests of vegetables collected in light trap in vegetable area at Jabalpur. M. Sc. Thesis, JNKVV, Jabalpur. 29$35 \mathrm{p}$.

Sabale, J.P., Chandana, Das and Samui, RP. 2010. Influence of weather factors on light trap catches of green leaf hopper at Pattambi, Kerala. Journal of Agrometeorology 12(1): 108-110.

Sabir, A.M., Sohail, Ahmed, Mansoor-UlHassan, Sahi, and Abdul, Qadir. 2006. Pest weather interaction of major insect pest in rice ecosystem. SAARC Journal of Agriculture 4: 203-212.

Shamim, M., Shekh, AM., Patel, V.J., Dodia, J.F., Korat, D.M., and Mehta, AM. 2009. Effect of weather parameters on population dynamics of green leaf hopper and white backed plant hopper in paddy grown in middle Gujarat region. Journal of Agrometeorology 11(2): 172-174.

Sharma, A.K. 2004. Scope of use of light trap as IPM tool in paddy ecosystem. Ph.D. Thesis, RDVV, Jabalpur. 1-136p.

Sharma, A.K., and Vaishampayan, SM. 2009. Evaluation of light trap as eco-friendly control tool in the management of insect pest species of paddy ecosystem. JNKVV Research Journal 44(2): 183 187.

Sharma, A.K., Barche, S., and Mishra, PK. 2013. Seasonal activity of Sogatella furcifera H., Cnaphalocropcis medinalis G. and Mythimna separata $\mathrm{W}$. in relation to weather parameters in Central India. Technofame Vol. (1): 19$29 \mathrm{p}$. 
Sharma, A.K., Vaishampayan, S., and Vaishampayan, SM. 2006. Distribution of insect pests fauna of rice ecosystem collected through light trap at Jabalpur. JNKVV Research Journal 40(1\&2): 5060.

Sharma, H.C., Sullivan, D.J., and Bhatnagar, VS. 2002. Population dynamics and natural mortality factors of the Oriental armyworm, Mythimna separate (Lepidoptera: Noctuidae), in South Central India. Crop Protection 21(9): 721-732.

Sharma, M.K., Asrat Atsedewoin, and Fanta, S. 2011. Forewarning models of the insects of paddy crop. International Journal of Biodiversity and Conservation 3(8): 367-375.

Shimoda, M., and Honda, K. 2013. Insect reactions to light and its applications to pest management. Applied Entomology and Zoology 48(4): 413-421.

Singh Devinder, and Ramaneek, HB. 2007. Population dynamics of Orthoptera (Insecta) collected from light trap. Journal of Entomological Research 31(1): 63-71.

Sinu, P.A., Picklu Mandal, Dipak Banerjee, Sadhan Mallick, Tapan Talukdar and Pathak, SK. 2013. Moth pests collected in light traps of tea plantations in North East India: species composition, seasonality and effect of habitat type. Current Science 104(5): 646-651.

Snedecor, G.W., and Cochran, WG. 1967. Statistical Methods. Oxford and IBH Publishing Company. New Delhi. 1-292 p.

Srinavasa, N., Viraktamath, C.A., and Sathyanarayana, J. 1991. Relative abundance of major insect pests of rice in light trap and their incidence in the field. Indian Journal of Entomology 53(4): 603-607.

Vaishampayan, SM. 2002. Use of light trap as a component of adult oriented strategy of pest management. Resources management in plant protection, Indian Hydrabad publication, 139-144p.

Venkatesh Hosamani, Pradeep, S., Sridhara, S., and Naik, MI. 2009. Incidence of rice earhead bug, Leptocorisa oratorius (F.) (Hemiptera: Alydidae) in Bhadra command area and effect of its feeding on grain damage. Environment and Ecology 27(2): 708-712.

Wang DaoZe, Hong WenYing, Wu YanJun, Wang AiJuan and Wei JiQian. 2012. Study on the occurrence regularity and prediction model of underground pest adults in Hangzhou district. [Chinese] Acta Agriculturae Zhejiangensis; 24(6): 1050-1057.

\section{How to cite this article:}

Meena, S.K., A.K. Sharma and Rajesh Aarwe. 2018. Seasonal Incidence and Population Dynamics of Major Insect Pest Species of Paddy Collected in Light Trap in Relation to Weather Parameters. Int.J.Curr.Microbiol.App.Sci. 7(08): 1705-1715. doi: https://doi.org/10.20546/ijcmas.2018.708.195 